AperTO - Archivio Istituzionale Open Access dell'Università di Torino

\title{
Loanword Formation in Minority Languages: Lexical Strata in Titsch and Töitschu
}

\section{This is a pre print version of the following article:}

Original Citation:

Availability:

This version is available http://hdl.handle.net/2318/1754692

since 2020-09-29T12:01:25Z

Publisher:

Edinburgh University Press

Terms of use:

Open Access

Anyone can freely access the full text of works made available as "Open Access". Works made available under a Creative Commons license can be used according to the terms and conditions of said license. Use of all other works requires consent of the right holder (author or publisher) if not exempted from copyright protection by the applicable law. 


\section{Part III Naming in Minority Languages}




\title{
Loanword Formation in Minority Languages: Lexical Strata in Titsch and Töitschu
}

\author{
Livio Gaeta and Marco Angster
}

This chapter discusses the growing effect of borrowing on the word formation of Titsch and Töitschu, two Walser German varieties spoken in Northwestern Italy. Even if both communities of speakers are surrounded by a Romance-speaking area, the two varieties display strikingly different results due to distinct histories of contact.

The chapter considers the case of verb borrowing and the collapse of the stratal condition constraining certain word formation rules to apply only to non-native bases in Töitschu, the development in both varieties of a productive class of action nominals unknown to Modern Standard German and the emergence in Töitschu of phrasal verbs linked to the more general syntactic remodelling sustained by this variety. The chapter is organised as follows: after the introduction, section 2 briefly introduces the Walser communities, while section 3 discusses the issue of lexical strata in these varieties largely exposed to contact. In section 4 one case of borrowing is presented which shows how a derivational paradigm can be enlarged in a creative way; section 5 shows how far the contact can go when basic design features of a language are involved, while the final section 6 draws the conclusion.

\section{A typology of borrowing phenomena}

A common truism says that the presence of foreign elements within a language is due to language contact, which inevitably takes place in bi- or multilinguals. However, the latter normally form only a (small) subset of a linguistic community, from which the foreign elements subsequently spread across the whole community. In fact, language contact is highly sensitive to, among other factors, the intensity of the contact, the number of bilinguals in a community and the prestige of the contact language.

Another widespread truism is that language contact normally affects the lexicon to a stronger degree than the other components of the grammar. As for word formation and the lexicon, loan material is generally argued to be organised in different strata constraining the domain of application of certain word formation rules to 
bases belonging to a specific stratum and usually opposing native and non-native morphemes, which broadly reflect the origin of the word (cf. Gaeta 2008 for a survey). For instance, German nouns ending with a full vowel are normally loans and take $-s$ in the plural: Kanu ('canoe') / Kanus, Kotau ('kowtow') / Kotaus, etc. Similarly, Russian loan nouns ending with $-o$ are normally neuter and invariable: pal'to ('coat'), metro ('underground'), etc. (cf. Timberlake 2004: 149). Finally, only English verbs belonging to the native stratum display the double-object alternation: Fohn gives / bequeaths / *donates / *delivers Mary a book (cf. Dixon 2005: 120). However, the strata need not be thought of in terms of the etymology of a word, which is mostly unknown to the speakers, but rather in terms of specific (phonological, morphological, syntactic) properties, and in fact German native words ending in a full vowel can also follow the s-pattern in the plural (e.g. Uhu 'eagle owl' / Uhus, Stau 'jam' / Staus) while an English verb like to pay, which is etymologically a loanword, also admits the double-object construction, i.e. has entered the native stratum.

The issue of language contact and its impact on the stratification of the lexicon become dramatic when bi- or multilingualism is the norm across a linguistic community as extensive contact can lead to a growing impact of borrowing phenomena on a language. In particular, we will aim to distinguish four phenomena:

- borrowing of specific patterns replicating and/or expanding the model occurring in the donor language;

- borrowing of specific patterns elaborated in a radically 'creative' way directly inspired by the donor language;

- borrowing of specific patterns elaborated in a radically 'creative' way not directly inspired by the donor language;

- borrowing of more general design properties filtering from the donor language.

This typology will be exemplified with the help of data drawn from two small Germanspeaking linguistic islands found in Northern Italy which provide the optimal candidates for investigating cases of widespread language contact, as we will briefly discuss below.

\section{Walser communities and data sources}

Walser communities in Piedmont and Aosta Valley date back to the spread of settlers coming from the upper Rhône Valley (Wallis, CH) speaking a variety of Highest Alemannic in the late Middle Ages (cf. Russ 1990). Walser communities are spread out over a vast, discontinuous territory in the Alps and usually occupy the highest settlements in the relevant valleys. In addition to Wallis, where their place of origin is recognised, and several other Swiss cantons (especially Graubünden), dialectologists and historians have been able to identify Walser communities in France, Liechtenstein, Western Austria (Vorarlberg) and Northwestern Italy (Piedmont and Aosta Valley). The Walser communities of the latter area are the focus of our interest.

At present, only a handful of communities still exist in Northwestern Italy. They occupy the upper part of the valleys on the southern side of the Alps around the Monte 
Rosa Massif and in Valle Antigorio. From North to South these communities are Formazza, Salecchio (and Bosco Gurin in nearby Canton Ticino, CH), Macugnaga, Rimella, Alagna in Piedmont and Gressoney and Issime in Aosta Valley. Even if they are geographically close to the border with Switzerland, some of the highest peaks in Europe separate most of these communities from Wallis and German speaking areas, thus making them linguistic islands in an Italian-speaking territory. Given their isolation from German-speaking areas, the small number of speakers (none of the relevant municipalities reaches 1,000 inhabitants) and the high altitude of these settlements (between 900 and 1,900 metres), these communities have witnessed a dramatic process of language shift in favour of Standard Italian and Gallo-Italic dialects in the last century. This has evidently had the effect of dramatically accelerating the process of language decay, ultimately leading to language death.

By contrast, during the same period the cultural prestige of Walser communities has increased, stimulating the birth of local cultural associations. The latter significantly enhanced the prestige of the Walser language and culture, promoting several publications of local amateurs, both in Italian and in the local language varieties, about traditional customs, historical, societal and environmental topics, as well as lexicographic works on which present orthographic conventions are based. This is a rich ethnographic and literary heritage that also constitutes a fundamental linguistic repertoire and a crucial source for researchers.

Two projects (DiWaC and ArchiWals, cf. Angster et al. 2017) have heavily drawn on this repertoire with the objective of collecting the textual and linguistic heritage and improving the documentation of the varieties considered by the projects (the varieties of Gressoney and Issime in Aosta Valley and those of Formazza, Rimella and Alagna in Piedmont, respectively). The data harvested are currently being uploaded to the variety-specific ArchiWals corpus (cf. www.archiwals.org) which will provide us with fine-grained searches enhancing corpus-based linguistic analyses on all varieties involved in the projects and which is the main source of the examples provided throughout this chapter.

\section{Lexical strata and borrowed patterns in Walser communities}

As mentioned in section 2 above, the Walser communities on the southern side of the Alps are surrounded by the Romance-speaking area and the speakers today are exposed to contact with (more than one) Romance variety. In this section, we will review the linguistic repertoire of Walser minorities in Italy and we will try to identify the most significant lexical strata recognisable in today's southern Walser lexicon. Finally, we will highlight the case of verbal borrowing in the varieties of Gressoney and Issime and the different outcomes of similar borrowing patterns.

\section{I Linguistic repertoires of the southern Walser communities}

Situated on the Germanic-Romance boundary, the southern Walser communities are a clear case of language contact and of multilingual communities. The Walser varieties are not the only linguistic varieties spoken there and it is highly probable that the 
neighbouring Romance dialects have slowly spread through these communities starting immediately after the time of first colonisation (cf. the survey in Eufe and Mader 2018). The sociolinguistic profile of each community is nonetheless different because, despite the relative proximity of the settlements as the crow flies, they often lie in separate valleys in which different Romance varieties are found (Francoprovençal in Aosta Valley, several varieties of Piedmontese in Aosta Valley and Valsesia, Ticinese Lombard varieties in Val d'Ossola).

The case of Gressoney and Issime in Aosta Valley is even more complex compared to the other southern Walser communities, and whose region, Piedmont, has only Italian as the official language, because these communities are part of an autonomous region in which French has had official status alongside Italian since at least 1948. However, despite being in the same autonomous region and even in the same valley, the two communities display a quite different sociolinguistic profile linked to a different history of contacts between German- and Romance-speaking areas. Following Zürrer (2009: 84ff.), we can summarise that, while Gressoney was a diglossic Germanspeaking community until the beginning of the twentieth century, with German serving as a written language and Piedmontese as an additional spoken variety beside Walser German, Issime already had a completely different repertoire at the beginning of the nineteenth century, with the complete absence of a written variety of German, French being the only written language and Francoprovençal as an additional spoken variety.

During the twentieth century this picture has further developed with the diffusion of Italian as a written language in both communities, the addition of French in Gressoney and the growing importance of Italian as a spoken variety, something which constitutes a general phenomenon in Italy, accompanied by a decrease of the use of Romance dialects (Berruto 2018: 498-500). Today, Walser German is strongly endangered and its transmission to young generations has almost been interrupted, while its realm of use is increasingly connected to the activities of the local cultural associations (Angster 2014: 115-119).

\subsection{Lexical strata at the Germanic-Romance encounter}

The dynamics of language contact and the historical development of language repertoires in the southern Walser varieties contributed in shaping the stratal composition of their lexicon. Angster and Dal Negro (2017: 13-14) provide a tentative subdivision of the lexicon of southern Walser varieties into four strata relating to three different donor languages, in addition to the ancestral Middle High German (GMH) stratum, which are used to classify the data included in the Atlas of Southern Walser German varieties (cf. Antonietti et al. 2015). In Figure 11.1 we charted Angster and Dal Negro's (2017) subdivision and adapted it to our purposes with the addition of a stratum of German varieties that is meant to include lexemes recognised as Germanic but not found in GMH. ${ }^{1}$

This German stratum forms a continuum stretching from arguably local lexical innovations to lexemes coming from other German varieties (and especially Swiss German). In fact, it is not easy to distinguish recent calques based on both Modern 


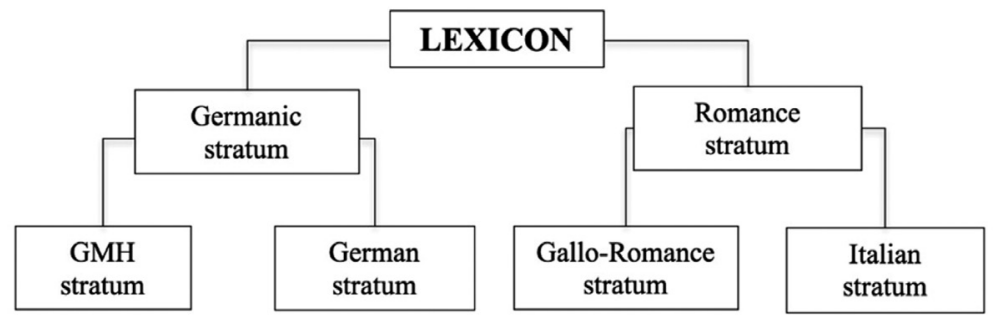

Figure 11.1 Language historical strata of southern Walser varieties

Standard German (DE) and Swiss German (GSW) such as, for instance, the form rägeboge ('rainbow'), found in Gressoney (see respectively DE Regenbogen and GSW Rëge(n)boge(n)), from arguably genuine local coinages like the Gressoney compound rägetach ('umbrella') (see DE Regenschirm and GSW Rëge(n)schirm, while a jocular form Rëge ( $n$ )dach is remarkably attested in GSW).

Furthermore, in Figure 11.1 a peculiar role is attributed to an Italian stratum as opposed to the rest of the Romance varieties as witnessed by words like television ('television') and schkossò ('electric shock') found in Gressoney. The rationale for this Italian stratum is the presence in these varieties of many recent borrowings drawn from (Standard or Regional) Italian, which contrast with arguably older borrowings which are clearly not part of the Italian lexicon. The borrowings of this second group, which constitute the Gallo-Romance stratum of Figure 11.1, form a heterogeneous set in which it is often hard to find out to which neighbouring Romance variety a word belongs. ${ }^{2}$ An example of these difficulties is visible in the lexeme for 'chair' (cf. Angster 2012), which in most communities is a borrowing from Romance varieties coming from Latin cathĕdra - through an unattested stage ${ }^{+}$catreca $^{3}$ - and not from Standard Italian, where 'chair' is sedia. It is worth noting that these borrowings undergo several phonological and morphological processes of adaptation. On the one hand, a change of stress position takes place assimilating the Romance lexemes stressed on the penultimate syllable to Germanic initial stress (e.g. see Zürrer 2009: 131 for Issime). On the other hand, the lexemes are integrated into the native inflectional class of feminine nouns ending in - $u$ : e.g. Issime mattu 'meadow', cognate of DE Matte 'mat, arch. meadow' (cf. Zürrer 2009: 133). Two different outcomes of Latin cathĕdra are attested.

(1) a. Mac. kadrjegu, Al. kariga, Rim. Kedrigu

b. Gr. karió, Is. karju ${ }^{4}$

Angster (2012: 188-189) shows that unreduced types like those attested in the Walser varieties spoken in Piedmont (1a), i.e. Macugnaga, Alagna and Rimella, are found in eastern Piedmontese and Lombard forms for 'chair'. On the other hand, reduced types of the kind found in the Walser varieties spoken in Aosta Valley (1b), i.e. Gressoney and Issime, are also attested in the Francoprovençal varieties of Aosta Valley as well as in the northwestern Piedmontese forms. Thus, it is impossible to draw any conclusion on which of the neighbouring varieties (either Francoprovençal or Piedmontese) might have served as source for the borrowing. 
To conclude this short survey of the lexical strata in the Walser German varieties, it is worth noting that, despite the presence of borrowings from Romance varieties, which reaches its peak in the case of the varieties of Issime and Rimella, a substantial amount of the lexemes analysed in Angster and Dal Negro (2017), about half of all lexemes, belong to the ancestral GMH stratum of the lexicon.

\subsection{Verbal borrowing in Gressoney and Issime}

In this section we will take the case of verbal borrowings into account to show how a borrowed pattern can interact with native patterns in Titsch and Töitschu, the varieties of Gressoney and Issime respectively.

DE displays a strategy to accommodate loan verbs, the stressed suffix -ier(en), whose history, development and expansion in the Germanic branch of Indo-European languages is sketched in Wohlgemuth (2009: 230-232). The suffix emerged already in GMH and occurred with loan verbs from Old French and Latin in texts of the twelfth and thirteenth centuries (Wohlgemuth 2009: 230). Interestingly, -ier(en) derives from the Old French infinitive suffix -ier of one inflectional class going back to a subset of Latin verbs in -āre whose stem ended in a palatal, like Old French jugier ('to judge') or traitier ('to treat') respectively from Latin iüdicāre and tractāre, and testifies therefore to an inflectional affix which developed into a derivational loan verb marker. ${ }^{5}$ Accordingly, when Old French verbs like logier ('to live') and turnier ('to tourney'), where -ier is an inflectional ending marking the infinitive form, were borrowed into GMH, the French inflectional ending -ier was retained phonologically, but re-analysed as a stressed verbal marker requiring the addition of the GMH inflectional endings and in particular the infinitive suffix -en: GMH losch-ier-en, turn-ier-en. The suffix -ier(en) has survived until the present and has in fact become extremely productive in DE (but also in German dialects, cf. Henzen 1965: 229) to form verbs, usually with non-native bases (Alarm 'alarm' $>$ alarmieren 'to alarm', Dose 'can' $>$ dosieren 'to dose', etc.), marginally with native bases (Gast 'guest' > gastieren 'to guest', Haus 'house' > hausieren 'to hawk').

Titsch behaves like DE and clearly displays a stressed loan verb marker $(=\mathrm{LVM})$-iere (the final $-e$ being the marker of the infinitive) found in a wealth of lexemes (slightly fewer than 100 formations in the Archiwals corpus) which in most cases parallel DE verbs and belong either to the Romance stratum, as in (2a), or to the Germanic one, as in (2b).

(2) a. datiere ('to date'), abkopiere ('to copy') (DE datieren, abkopieren)

b. halbiere ('to divide'), schattiere ('to shade') (DE halbieren, schattieren)

However, in some cases we also recognise formations based on Italian verbs which are unknown to DE (3a).

(3) a. arif-ier-e $<$ IT arrivare ('to arrive')

arrive-LVM-INF

('to arrive') 
b. én-bòtòl-ier-e $\quad<\quad$ IT imbottigliare ('to bottle')

in-bottle-LVM-INF

('to bottle')

Note that the prefix én- in (3b), based on bòtellò ('bottle'), is also found in other formations like énkassiere ('to cash in') (cf. DE einkassieren, IT incassare) or énterniere ('to inter') (cf. DE internieren, IT internare), and has to be analysed as the cognate of DE ein-found in ein-flasch-en ('to bottle') and cannot be taken as a borrowing from the corresponding Italian prefix in- of imbottigliare, because in the latter case we would expect place assimilation of the nasal.

We now turn our attention to Töitschu, where instead of -ier(en) an unstressed verb marker -urun is found, as illustrated in (4).

(4) a. kassurun ('to break'), offensurun ('to offend'), pünnurun ('to punish'), remmursiurun ('to thank')

b. casser ('to break'), offenser ('to offend'), punir ('to punish'), remercier ('to thank')

Zürrer (2009: 136-138) analyses the words in (4a) as hybrid formations consisting of a lexical part borrowed from the contact language - in this case French: cf. the words in (4b) - and of a morphological part, i.e. -urun, that he recognises as native. This ending is taken to be directly connected to the lexical root of the borrowed verbs, respectively offens-, pun-, remerci- and cass-, stripped of their original inflectional suffixes, i.e. $-e r$ and -ir. Zürrer (2009) traces the origin of the marker -ur-back to a set of native verbs belonging to the class of verbs ending in -un which display the phonological segment $-u r$ - before the infinitive ending $-u n .{ }^{6}$ In dependence of the nature of this element, three different groups have to be distinguished:

1. deadjectival verbs, in which the base of the comparative is used: ar-breit-urun ('to widen') < brait-ur, comparative form of brait ('wide');

2. denominal verbs, in which the base noun displays the purely phonological ending -er: hunghur-un ('to go hungry, to starve') < hungher ('hunger');

3. denominal verbs, in which the base of the plural formed with the suffix -er is used: chalb-ur-un ('to calve') < chalb-er, plural form of chalb ('calve').

Each of the three groups has parallels in DE or in other German varieties: cf. DE verbreitern ('to widen'), hungern ('to go hungry, to starve'), and GSW kalbern ('to calve') (cf. DE kalben) respectively. It is important to stress that -er-becomes -ur-due to backward vowel harmony triggered by the ending -un .

Zürrer (2009: 137) argues that starting from these native formations the speakers interpreted the sequence of $-u r$ - and $-u n$ as a single morpheme -urun (which also parallels GSW -ere and DE -ern) and started to apply it productively to verbs coming from the contact languages (French and to a lesser extent Italian) to adapt borrowings. The adaptation affects also the phonological make-up of these borrowed verbs, which results in the stress pattern of native words with stress on the first syllable (cf. also section 3.2 above). For instance, French regretter ('to regret'), stressed on the last 
syllable, is adapted as ['re]grutturun, while Italian spostare ('to move away'), stressed on the penultimate syllable, becomes [a'spos]turun stressed on the second syllable because the first syllable is re-analysed as a so-called 'non-separable' unstressed prefix.

We must add, to complete the picture reconstructed by Zürrer (2009), that apart from the loan verbs in (4a) and the three groups of verbs derived from native bases discussed above, -urun occurs also with native bases, as illustrated in (5).

(5) a. blétschurun ('to snow-spot') < blétschu ('snow-spot') gitzunurun ('to give birth to a goatling') < gitzu ('goatling')

b. bisseturun ('to nibble') $<$ bissetu ('snack') $<$ biss ('bite') schowuturun ('to kick one's legs') $<$ schowutu ('kick') $<$ schu ('shoe')

With native nouns in which no etymological ending -er occurs, as in (5a), and with native nouns derived by means of the suffix $-e t u /-u t u$, as in (5b), we also find -urun. ${ }^{7}$ Quite surprisingly, however, Zürrer (2009) does not mention the possibility that -urun might be the local outcome of GMH -ieren even though in Töitschu as well as in Titsch we find a long series of parallel formations as shown in Table 11.1.

In Table 11.1 the Töitschu verbs corresponding to DE forms as well as their corresponding French verbs are highlighted in dark grey. When no close similarity with DE forms is found, the Töitschu verbs either correspond to Italian verbs as shown by the forms highlighted in light grey in Table 11.1, kurrudŝshurun, livelurun, or they slightly deviate from any of the available models as shown by the forms akupiurun and astüdiurun.

While in the case of Gressoney the contacts with German-speaking areas documented until recent times offer themselves as an explanation of the presence of a postGMH stratum of German - not necessarily Germanic - lexicon to which most -ieren formations belong, in the case of Issime the presence of such a stratum is harder

Table 11.1 Borrowed verbs in DE, Titsch and Töitschu compared with FR and IT

\begin{tabular}{llllll}
\hline DE & Titsch & Töitschu & FR & IT & \\
\hline abkopieren & abkòpiere & akupiurun & copier & copiare & ('to copy') \\
diktieren & diktiere & dikturun & dicter & dettare & ('to dictate') \\
funktionieren & fònziòniere & funktiunurun & fonctionner & funzionare & ('to function') \\
garnieren & garniere & garnurun & garner & $\begin{array}{l}\text { decorare, } \\
\text { guarnire }\end{array}$ & $\begin{array}{l}\text { ('to decorate, } \\
\text { to garnish') }\end{array}$ \\
korrigieren & kòrregiere & kurrudŝchurun & corriger & correggere & ('to correct') \\
nivellieren & liwelliere & livelurun & niveler & livellare & ('to level') \\
panieren & paniere & pannurun & paner & impanare & ('to bread, to \\
spionieren & spiòniere & aspéjunurun & épier & spiare & ('to spy') \\
studieren & studiere & astüdiurun & étudier & studiare & ('to study') \\
\hline
\end{tabular}


to explain. This is because of the interruption - at least as early as the nineteenth century - of substantial contacts with German-speaking areas discussed in section 3.1 above. This state of affairs lends apparent support to Zürrer's view, which opposes the development of -iere in Titsch from the GMH suffix -ieren to the peculiar development of -urun in Töitschu that is taken to be related only indirectly to the GMH loan suffix -ieren.

However, in our opinion the presence of a series of parallel formations displaying-ieren/-iere/-urun in DE, in Titsch and in Töitschu requires an explanation. In fact, if we look at the Töitschu data extracted from the Archiwals corpus a clear asymmetry is observed, as illustrated in (6).

(6) a. aksepturun ('to accept'), markurun ('to mark') (cf. DE akzeptieren, markieren) b. arwéiturun ('to widen'), joamurun ('to lament') (cf. DE erweitern, jammern)

The verbs in -urun based on Romance bases (6a) outrank -urun verbs corresponding to $\mathrm{DE}$-ern verbs (6b) by a factor of five to one (the former group includes about 250 formations, the latter approximately fifty). Moreover, the possible common origin of -iere and -urun going back to GMH -ieren is not contradicted stricto sensu by the interruption of direct relations with the German-speaking areas by the Issime community in the nineteenth century.

On the other hand, -iere and -urun display remarkable differences which make the hypothesis of a direct relation of -urun with GMH -ieren difficult to accept and in search of support through further evidence. In this regard, we have already mentioned above that in Töitschu, backward vowel harmony has the effect of assimilating the unstressed vowels to the back vowel of the final syllable (cf. Zürrer 1999: 148-153 for a description of the phenomenon in inflected forms). Backward vowel harmony stands in a feeding relation with stress retraction to the first syllable in borrowings, because the latter has the effect of leaving the suffix -ier- unstressed and open to the influence of the back vowel of the following syllable -un (cf. section 3.2 above).

If this is enough to account for the form -urun instead of -ierun, we still have to explain why the borrowings are integrated into the class of -un verbs in spite of the occurrence in Töitschu of a verb class with $-e n$ which goes back to the GOH class $-\bar{e} n$, as shown by the verb chaufen ('to buy'). In this context, we should consider the examples in (7).

(7) a. spigal ('mirror') $>$ spiglun ('to mirror'), stul ('stool, pile, stack') $>$ stulun ('stack up'), vröin ('friend') $>$ vröinun ('to befriend')

b. gelw ('yellow') $>$ gelwen ('to yellow'), gruass ('big') $>$ gruassen ('to grow larger')

Besides the verbs going back to the GOH -ōn class, as for instance machun ('to make'), or displaying the verb marker -urun seen above, we also find dozens of denominal -un verbs derived from native stems displaying a causative or inchoative meaning (7a). ${ }^{8}$ On the other hand, $-e n$ verbs are also derived to a limited extent from adjectival bases, modelling an inchoative meaning (7b). 
In this light, we can formulate the hypothesis that the class of -un verbs was at some point the default class used to expand the stock of verbal lexemes in Töitschu. When the first-ieren verbs were borrowed, they underwent a process of adaptation consisting of three steps:

1. inclusion into the default class of -un verbs: diktieren $>^{+}$diktierun;

2. stress retraction to the first syllable: ${ }^{+} d i k[$ 'ti: $]$ run $>^{+}[$'dik $]$tierun;

3 . assimilation of the penultimate syllable to $-u$ - due to backward vowel harmony: ${ }^{+}[$'dik $]$tierun $>\left[{ }^{\text {dikt }}\right]$ run.

The effects of backward vowel harmony produced the merge of the group of loan verbs originally formed with the GMH suffix -ieren and the group of native verbs corresponding to DE -ern formations. In fact, since the default suffix -un was also used to form verbs like ${ }^{+}$arbreiterun, ${ }^{+}$hungerun and ${ }^{+}$chalberun (cf. GOH hungirōn), backward vowel harmony caused a full neutralisation between the two groups of verbs. This also led to the disruption of the stratal condition constraining the domain of application of certain word formation rules to bases belonging to a specific stratum. This condition is still valid in Titsch, where the suffix -iere is mostly restricted to non-native bases (8a) and the outcomes of the -ern verbs (8b) are kept neatly distinct.

(8) a. dosiere ('to dose'), fantasiere ('to fantasise'), kontròliere ('to control') (cf. DE dosieren, phantasieren, kontrollieren)

b. verbreitrò ('to widen'), hòngrò ('to hunger'), chalbrò ('to calve') (cf. DE verbreitern, hungern, kalbern)

As a consequence, the suffix -urun in Töitschu appears nowadays as a productive means to integrate loan verbs in the lexicon, but also to form new verbs from local neologisms. At the same time, this shows that the peculiar development of Töitschu has led to a collapse of the synchronic relevance of the well-tailored strata depicted in Figure 11.1 above which appear to be still relevant for Titsch.

\section{Creative elaboration of borrowed patterns}

In this section we will turn our attention to action nouns in order to show how far the creative elaboration of a borrowed pattern can go in enriching a well-defined derivational paradigm (see Štekauer 2014 for the latter concept).

\section{I Action nouns in Greschòneytitsch}

Like any well-behaved Germanic language, the derivational paradigm of action nouns both in Titsch and in Töitschu consists of the five different patterns displayed in Table 11.2. ${ }^{9}$

As is shown by the figures in Table 11.2, the commonest ways to form action nouns in Titsch rely respectively on the suffix -òng (a), on the root-vowel alternations typical of Germanic languages (b) and on conversion (c). In addition, a number of other minor types occur (e), displaying further suffixes like $-e ́$ and $-(t) s c h t$, possibly in combination 
Table 11.2 The derivational paradigm of action nouns in Titsch and their DE equivalents

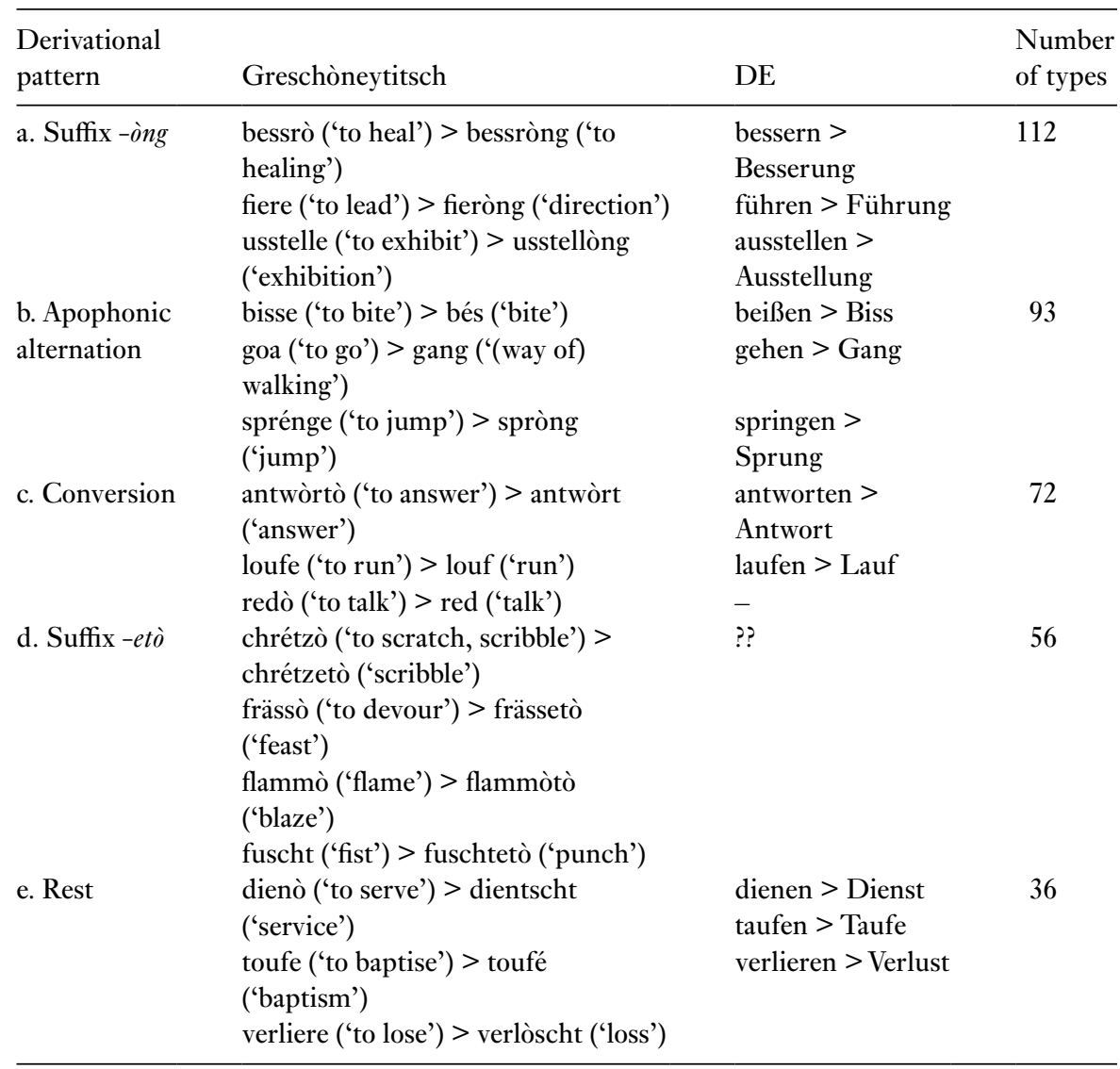

with apophony. Quite surprisingly, however, a further type (d) is robustly attested, which displays the feminine suffix -etò in combination with both verbal and nominal bases. In Töitschu, the suffix displays the form -etu or -utu in compliance with the vowel harmony discussed above: chratzun ('to scratch') > chratzetu ('scratch'), messer ('knife') > messerutu ('knifing'), etc. ${ }^{10}$ Note that in contrast to the other types no clear equivalent of this suffix occurs in DE. On the other hand, this suffix is cognate with the feminine suffix -ete frequently found in High Alemannic and in Swabian referring to the abstract or concrete result of an activity, i.e. a certain quantity appearing at once, e.g. Schü̈sete ('a shooting') and Verschimpfete ('a scolding') (cf. Russ 1990: 359, 379). ${ }^{11}$ This suffix is taken to go back to a Latin or Romance ending, - $\bar{t} t a$ or $-\bar{e} t a$, which is attested in a few GOH borrowings like miscellāta ('mixture'), scizzāta ('dung'), bliumāta ('hitting'), screiāta ('shouting'), snuderāta ('snot') (cf. Henzen 1965: 175). Note incidentally that the endings $-\grave{o}$ and $-u$ represent the normal way of adapting $a$-ending feminines coming from Romance languages in Titsch and Töitschu: e.g. Italian gara ('race') > Ti. garò, 
It. benna ('excavator grab') > Tö. bennu, etc. Moreover, these endings also represent the normal outcome of the old Germanic feminines reduced to Schwa in DE: Ti. klockò / Tö. klocku / DE Glocke ('bell'), Ti. seifò / Tö. seifu / DE Seife ('soap'), etc.

While their history and occurrence in Titsch and Töitschu are perfectly in line with the widespread diffusion of the suffix -ete in High Alemannic, the profile of the derivatives formed with the suffixes -etò and -etu is worth further investigation as it shows a consistent picture and displays striking similarity with a quite productive pattern found also in Italian and in other Romance varieties, but found only to a limited extent in French.

\subsection{Derivatives formed with -etòl-etu}

The derivatives formed with the suffix -etò/-etu come from two lexical bases, verbs and nouns. As for deverbal nouns, they typically select verbs denoting unbounded or atelic activities in Vendler's (1967) sense and produce action nouns provided with the meaning roughly sketched above.

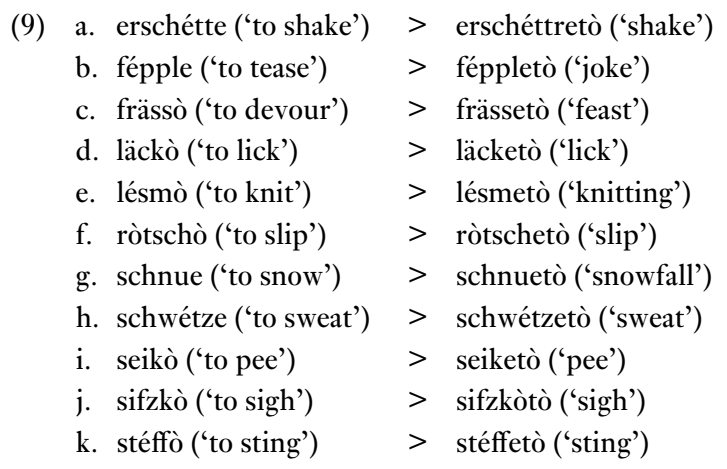

The activities can presuppose a human or more generally an animate agent as in $(9 \mathrm{~b}-\mathrm{e})$, or a non-volitional experiencer as in $(9 \mathrm{f})$ and $(9 \mathrm{j})$, or they can make reference to natural processes as in $(9 \mathrm{~g}-\mathrm{h})$, or they can profile either agentless natural processes or an agent lurking behind them as in $(9 \mathrm{a}),(9 \mathrm{i})$ and $(9 \mathrm{k})$. The crucial property, however, is that the activity is temporally unbounded while the derivative produces its corresponding bounded or semelfactive action noun referring to 'a single instantiation of the activity denoted by the base' which can easily be pluralised. A more varied picture emerges for denominal verbs.

$\begin{array}{lll}\text { (10) a. chorb ('basket') } & > & \text { chorbetò ('basketful') } \\ \text { b. flammò ('flame') } & > & \text { flammòtò ('blaze') } \\ \text { c. fuscht ('fist') } & > & \text { fuschtetò ('punch') } \\ \text { d. gabelò ('fork') } & > & \text { gabletò ('pitchfork') } \\ \text { e. hòre ('horn') } & > & \text { hòrnetò ('butt') } \\ \text { f. leffél ('spoon') } & > & \text { leffietò ('spoonful') } \\ \text { g. oug ('eye') } & > & \text { ougetò ('glance') }\end{array}$


These basically display three different meanings: (1) 'single quantity contained in $\mathrm{N}^{\prime}$ ' if the base is a possible container, as in (10a) and (10f), or can be conceptualised as such as in (10d); (2) 'single blow of $\mathrm{N}$ ' if the base is a possible instrument as in (10c) and (10e); (3) 'single instantiation of the activity involving $N$ ' if the base can be conceptualised as involving an activity as in (10b) and (10g). Note that the same derivatives can display different meanings: gabletò can also have the blow meaning, while fuschtetò can be conceptualised as referring to the typical activity involving a fuscht. On the other hand, ougetò can also be intended as a metaphorical blow of eye. Because of this intrinsic polysemy, it seems more plausible to assume a general, unspecified meaning 'single instantiation of a typical (abstract or concrete) property of the base'.

Finally, since verbs can be easily derived from nouns by means of conversion, in cases such as (11) both analyses are available, resulting in a double motivation.

(11) a. blétzk / blétzkò ('to flash')

b. fues ('foot') / fuessò ('to kick')

c. hoamer ('hammer') / hoamrò ('to hammer')

d. näscht ('nest') / näschtò ('to brood')

e. peitschò ('lash / to lash')

f. messer ('knife') / messrò ('to knife')

g. stäcke ('stick') / stäckò ('to beat with a stick')

h. tésch ('table') / tésschò ('to set the table') > tésschetò ('tableful')

This state of affairs supports the idea of a general, unspecified meaning which captures both deverbal and denominal derivatives stressing the unity of the derivational process involving -etò.

\subsection{The Italian feminine past participle and -etòl-etu}

In addition to the unspecified category of the base discussed in section 4.2 , a second property of these suffixes is the striking similarity with the Italian (and, more in general, Romance, cf. Gaeta 2015) semelfactive action nouns that take the feminine form of the past participle: mangiare ('to eat') $>$ mangiata (past part. mangiato), cadere ('to fall') $>$ caduta (past part. caduto), etc. The semelfactive action noun can be characterised in all Romance languages (with the noteworthy exception of Romanian) as meaning 'a single instantiation of an activity typically connected with the base'.

They are provided with peculiar properties as they form bounded action nouns, typically from activity verbs, and flank other action nouns formed on the same bases, in particular those displaying the highly productive suffixes -mento and-zione as in (12a) and (12b) (cf. Gaeta 2002, 2017).

(12) a. insaponare ('to soap') > insaponamento ('soaping') / insaponata

b. accelerare ('to speed up') $>$ accelerazione ('acceleration') / accelerata

c. cadere ('to fall') > caduta ('fall') $/ *$ cadimento / *cadizione

d. entrare ('to enter') > entrata ('entrance') / *entramento / *entrazione 
Note, incidentally, that with unaccusative verbs this double series of derivatives from the same base is blocked as shown by (12c) and (12d). This is arguably due to the basic meaning of this procedure which can be formally expressed with the help of Booij's (2010) constructional framework.

(13) a. $\left[[\ldots]_{\mathrm{Vi}}-\text { mento/-zione }\right]_{\mathrm{Nj}} \leftrightarrow\left[\text { the SitTyp involved by } \mathrm{SEM}_{\mathrm{i}} \ldots\right]_{\mathrm{j}}$

b. $\left[[\ldots<+ \text { dyn, }-\mathrm{b}>]_{\mathrm{Vi}} \mathrm{FPP}\right]_{\mathrm{Nj}} \leftrightarrow\left[\text { the SitTyp }<+\mathrm{b}>_{\mathrm{j}} \text { combined with } \mathrm{SEM}_{\mathrm{i}} \ldots\right]_{\mathrm{j}}$

While the suffixes -mento and -zione do not display any particular selectional properties in that any verbal base can be taken to form an action noun denoting the situational type (SitTyp) identified by the basic meaning (SEM) of the verb (13a), the derivatives formed with the feminine past participle (FPP) are essentially more selective (13b). In fact, they only take dynamic $<+$ dyn $>$ and unbounded $<-b>$ verbs and form nouns referring to a bounded $<+b>$ SitTyp. With unaccusative verbs the application of the latter pattern applies at the output value insofar as their semelfactive meaning is immediately mirrored in the bounded nature of the Sit Typ and blocks the possible selection of the other less restricted pattern. Such a mechanism in which a pattern is applied at the output value is well accommodated in Booij's constructional framework insofar as word formation patterns are expressed by means of lexical relations among partially specified constructions instead of rules presupposing an input-output relation.

Moreover, a suffix -ata, which actually corresponds to the specific form of the FPP of the default class -are, also combines with nominal bases displaying a number of meanings that basically correspond to those listed in (10) above for -etò also with respect to possible intrinsic polysemy as in $(14 \mathrm{a}) .{ }^{12}$

(14) a. forchetta ('fork') > forchettata ('fork full/pitchfork')

b. gomito ('elbow') > gomitata ('jab')

c. occhio ('eye') > occhiata ('glance')

Finally, in several cases a double motivation shows up, as illustrated in (15).

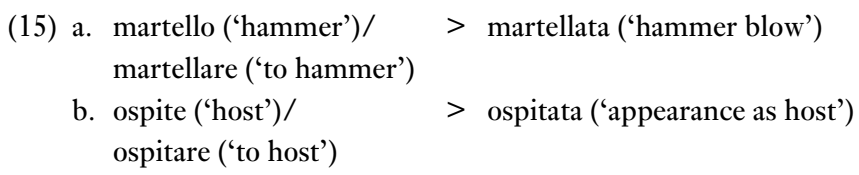

Given the strict correspondence of the FPP and the -etò derivatives, it is straightforward to assume that a direct connection between the two patterns exists in the bilingual speaker's mind insofar as the Italian pattern supports and enhances the development of -etò, i.e. of the weak code. Some examples of corresponding pairs are given in (16).

$\begin{array}{llll}\text { (16) a. ròtschetò } & \text { scivolata } & \text { ('slip') } \\ \text { b. schnuetò } & \text { nevicata } & \text { ('snowfall') } \\ \text { c. schwétzetò } & \text { sudata } & \text { ('sweat') }\end{array}$



d. seiketò
pisciata
('pee')
e. gabletò
forchettata ('pitchfork')
f. hòrnetò
('butt')
g. ougeto
cornata
('glance')
h. hoamretò
occhiata
('hammer blow')

In fact, such a development has the effect of enlarging the derivational family of Titsch action nouns insofar as two types of action nouns can be formed from the same base, depending on the word formation pattern selected as shown by $(17 \mathrm{a}-\mathrm{b})$ and $(17 \mathrm{c}-\mathrm{d})$, respectively.

(17) a. $\left[[\ldots]_{\mathrm{Vi}}-\grave{o n g}\right]_{\mathrm{Nj}} \leftrightarrow\left[\text { the SitTyp involved by } \operatorname{SEM}_{\mathrm{i}} \ldots\right]_{\mathrm{j}}$

b. erschétte / scuotere $\rightarrow$ erschéttròng / scuotimento | action noun $\mid$

c. $\left[[\ldots<+ \text { dyn, }-\mathrm{b}>]_{\mathrm{Vi}}-e t \grave{o}\right]_{\mathrm{Ni}} \leftrightarrow\left[\text { the SitTyp }<+\mathrm{b}>_{\mathrm{j}} \text { combined with } \operatorname{SEM}_{\mathrm{i}} \ldots\right]_{\mathrm{j}}$

d. erschétte / scuotere $\rightarrow$ erschéttretò / scossa | semelfactive action noun|

Note that unaccusative verbs normally select other procedures to form action nouns, namely the conversion pattern (see (c) in Table 11.2 above, e.g. falle 'to fall' $>$ fall, loufe 'to run' > louf, cf. DE fallen $>$ Fall, laufen $>$ Lauf), or the apophonic pattern possibly in combination with the suffix $-t$ (see (e) in Table 11.2 above, e.g. achéeme 'to arrive' > ankònft, cf. DE ankommen > Ankunft). However, in a few cases where an unaccusative verb selects $-e t \grave{o} /-u t u$, other action nouns are normally blocked: ròtschò ('to slip') > ròtschetò / * ròtsch / *ròtschòng (cf. DE rutschen 'to slip' > Rutsch / Rutschung), mirroring the similar blocking effect observed for the Italian FPP in (12c-d) above.

Finally, the derivatives with -etò/-utu are particularly useful in periphrases selecting a support verb like geen ('to give'). In (18), from Töitschu, this expresses a particular emphasis on a single event extracted from a sequence of similar events. ${ }^{13}$

(18) hets

has.3sG.N

gwettrut un hets

hets rain.PSTPTCP and

has.3SG.N

dondurut,

has.3SG

keen an dondurutu

thunder.PSTPTCP

'It has rained and thundered, there has been a stroke of thunder [sic] which has broken a larch.'

This construction closely resembles the quite frequent Italian model exemplified in (19), which, similarly to English (cf. Dixon 2005: 459ff.), also has the effect of emphasising a single instantiation of the depicted event and selects the support verbs fare ('make') and dare ('give'), accompanied by an indefinite NP containing a FPP (cf. Gaeta 2002: 159ff.).

(19) Ha fatto una gran tuonata che ha spaccato un larice has made a big thunder.FPP that has broken a larch 'There has been a big thunder which has broken a larch.' 
Moreover, this construction is completely unknown in DE in which support verb constructions (DE Funktionsverbgefüge 'sequences with function verb') are quite widespread, but with an essentially different structure and value where the particular emphasis on a single instantiation of the event is absent (cf. Storrer 2006 for a survey).

\subsection{The role of the Romance diminutive}

A last observation on the development of the suffix -etò / -utu relates to the possible influence of the feminine form of the Romance diminutive suffix -etta / -ette as it appears in a number of loanwords. Some examples are given in (20).

(20) a. FrProv. brotsetta > Ti. brotschetò / Tö. brotschetu ('faucet')

b. Fr. serviette $>$ Ti. schärvietò / Tö. sarvietu ('napkin')

c. FrProv. terretta > Ti. tärretò / Tö. terrutu ('tureen')

As we have already seen above, the feminine ending $-a$ is normally adapted as $-\grave{o}$ in Titsch and as $-u$ in Töitschu which continue the old endings of the Germanic feminines reduced to Schwa in DE. The influence of this pattern can be seen in the extension of the ending -etò / -utu to native nouns like Ti. gòrbetò ('bill hook') (going back to GOH churba from Lat. curvus 'bowed'), or in cases where the etymological ending might be matched with -etò such as Ti. ruetò ('rod' from GOH ruota cf. DE Rute) or Tö. retzetu from Fr. recette ('recipe' cf. DE Rezept), and crucially in nouns like Ti. chorb / Tö. chuarb ('basket'), Ti. oug / Tö aug ('eye'), etc. where a diminutive value was possible. The acquisition of the semelfactive action value, replicating the Italian model, might have been favoured by the frequent meaning extension 'diminutive' $>$ 'singulative', as found for instance in It. zuccherino 'small sugar > piece of sugar' and in many other languages (cf. Grandi 2015 for a survey). In sum, the old loan suffix - etò / -utu, ultimately coming from Romance-ata, has been partially enhanced by its formal identity with borrowings displaying a Romance diminutive suffix -etta, which - in spite of its etymological difference - has crossed its way with the old suffix via a common process of meaning extension.

\section{Borrowing more general design properties}

The borrowing of general design properties of a language is normally said to be possible only in the presence of dramatic changes caused by the generalised effects of language contact (cf. some discussion in Wohlgemuth 2009: 11-17). In this regard, we already observed how Töitschu, under a stronger influence of the surrounding Romance languages, gave up the stratal distinction between a Germanic and a Romance stratum discussed in Figure 11.1 above, which is perfectly preserved in Titsch. This is illustrated in (21).

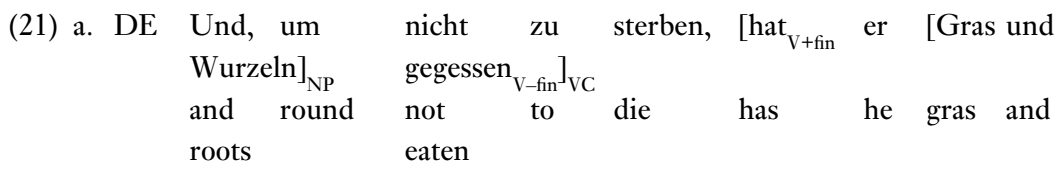




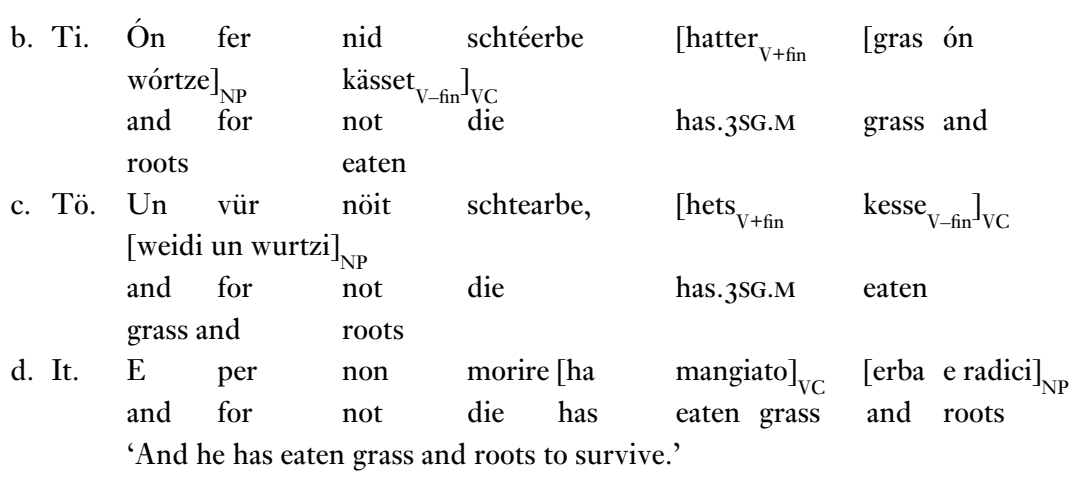

In (21a), we find that in DE the so-called sentence bracket is determined by the two components of the complex verb. One bracket is the finite component in second position, the other the non-finite components in final position. The subject and the object are in between them, in the so-called middle field. In Titsch, this structure is maintained, as in (21b). However, in Töitschu the entire idea of a sentence bracket, including the middle field, is lost. Thus, the two components of the complex verb in (21c) are placed together, as they are in Italian (21d).

As is well known, in DE a similar sentence bracket is found with so-called particle verbs in which the particle element is separate from the lexical root and dislocated at the end of the sentence either alone (22a) or in combination with the non-finite component of the verbal complex (22b), in contrast to prefix verbs where separation is impossible (22c).

(22) a. Er ass Gras und Wurzeln auf / *aufass /*ass

auf Gras und Wurzeln he ate grass and roots up / *up.ate / *ate up grass and roots 'He ate grass and roots up.'

b. Er hat Gras und Wurzeln aufgegessen / *gegessen auf Gras und Wurzeln. he has grass and roots up.eaten /*eaten up grass and roots 'He has eaten grass and roots up.'

c. Die Motten zerfrassen die Kleider /*frassen die Kleider zer. 'The moths ate away at the clothes.'

In concomitance with the loss of the general design property relating to the sentence structure, in Töitschu (23b) also particle verbs have disappeared in favour of phrasal verbs, while particle verbs are well preserved in Titsch (23a).

(23) a. Ti. heintsch demnoa Heilége mét dem water
have.3PL hence saints with the weather
zéemegleit / *gleit zéeme
together.put.PSTPTCP
'Hence they have combined the Saints with the weather.


Table 11.3 Particle verbs in Titsch and their correspondents in Töitschu

\begin{tabular}{|c|c|c|c|c|c|}
\hline \multicolumn{2}{|c|}{ Particle verbs } & \multicolumn{3}{|c|}{ Phrasal verbs } & \\
\hline Titsch & DE & Töitschu & Piedmontese & Northern Italian & 6 \\
\hline $\begin{array}{l}\text { alecke } \\
\text { drélecke }\end{array}$ & $\begin{array}{l}\text { anlegen } \\
\text { hereinlegen }\end{array}$ & $\begin{array}{l}\text { lecken a } \\
\text { lécken i }\end{array}$ & & & ('to put in') \\
\hline élecke & einlegen & lécken dri & büté 'ndrinta & mettere dentro & ('to put inside') \\
\hline embrélecke & niederlegen & & büté giü & mettere giù & ('to put down') \\
\hline uflecke & auflegen & lécken ouf & büté sü & mettere su & ('to put up') \\
\hline uslecke & auslegen & lécken ous & büté fora & metter fuori & ('to put out') \\
\hline vorlecke & vorlegen & lécken vür & & & ('to put forward') \\
\hline zuelecke & zulegen & lécken zu & & & ('to put to') \\
\hline zéemelecke & zusammenlegen & lécken zseeme & $\begin{array}{l}\text { büté 'nsema } \\
\text { büté via }\end{array}$ & $\begin{array}{l}\text { mettere insieme } \\
\text { mettere via }\end{array}$ & $\begin{array}{l}\text { ('to put together') } \\
\text { ('to put away') }\end{array}$ \\
\hline
\end{tabular}

b. Tö. $z$ bruat hescht gleit i/*igleit sua

the bread have.2SG put.PSTPART in so

'You have put the bread inside in this way.'

The re-analysis of particle verbs as phrasal verbs consisting of a verb immediately followed by a locative adverb is a generalised feature throughout the Töitschu lexicon, which stands in neat contrast with the conservative behaviour of Titsch resembling DE. This is illustrated in the contrasting examples in Table 11.3.

On the other hand, phrasal verbs are commonly found in Piedmontese and more in general in the Northern Italian varieties spoken there. Again, the disruption of the general design property relating to the sentence structure observed in Töitschu brings along the remodelling of a peculiar derivational pattern, the particle verbs, according to the syntactic model occurring in contact languages.

\section{Conclusion}

To sum up, intensive contact can lead to extensive borrowing of patterns of a growing complexity. In this regard, striking differences have been observed between the two Walser German varieties of Gressoney and Issime, which are both surrounded by Romance languages but display a significantly different contact situation.

As for the simple borrowing of morphological material, intensive contact can lead to the disruption of the stratal condition, as in the case of the suffix -urun in Töitschu with respect to its cognate -iere in Titsch and in DE. The case of the Titsch and Töitschu action nouns in -etò / -utu shows that in the presence of intensive contact the derivational category of action nouns has acquired a new pattern which is very salient in the bilinguals' mind and has been partially elaborated in a creative way, combining morphological substance of a completely different etymological origin. Finally, borrowing more complex design features such as the pattern of phrasal verbs observed in Töitschu has to be related to its general 
syntactic remodelling compared to Titsch insofar as the former has completely given up the bracket sentence still preserved in the latter in favour of the Romance pattern.

\section{Acknowledgements}

Parts of this chapter were presented at the Workshop 'Interaction of Borrowing and Word-formation' held during the 50th International Annual Meeting of the Societas Linguistica Europaea (Zürich, September 2017). We are very grateful to those who attending our talk and especially to Guido Seiler and Angela Ralli for their observations, as well as to Pius ten Hacken and Renáta Panocová. Needless to say, we are solely responsible for the views expressed and any remaining mistakes.

The general outline of the chapter, the analysis of the data and the drafting of the introduction and conclusion are due to a joint effort of both authors, however Marco Angster is responsible for sections 2-3 and Livio Gaeta for sections 4-5.

\section{Notes}

1. Note that in Figure 11.1 the ancestral GMH stratum also includes borrowings coming from Latin and Romance which are to be considered completely nativised, such as for instance chaufen ('to buy') and schréiben ('to write') found in Issime, and which are based respectively on Latin caupō ('innkeeper, retail dealer') / caupōnārì ('to chaffer') and on Latin scribere ('to write'), already attested in the Old High German (GOH) borrowings koufen and scriban.

2. Under Gallo-Romance we intend both Gallo-Romance varieties (e.g. Francoprovençal) and Gallo-Italic varieties (e.g. Piedmontese). The choice is made for simplicity's sake, but also because in the geographical area here considered the two dialectal domains border and, to some extent, overlap.

3. The ${ }^{+}$indicates a reconstructed form for which there is no evidence in written records.

4. In this chapter, all examples of Walser German or Romance varieties are written using the local writing system or as they are cited in the relevant sources. Note in particular the signs <é $>$ and $<\grave{o}>$ found in Gressoney which roughly correspond respectively to [I] and [ $\mathrm{\mho}]$. This implies that words can be written differently even if they sound alike (e.g. Gressoney karió and Issime karju are both ['karjo]).

5. By the end of the thirteenth century, the inflectional class with -ier had already merged again with the class ending in -er in Old French (cf. Wohlgemuth 2009: 230).

6. The class of -un verbs in Issime developed historically from the second class of GOH weak verbs in $-\bar{o} n$. While already in the GMH period elsewhere in the German-speaking area this class merged with the $\mathrm{GOH}-\bar{e} n$ class, it is retained in the Swiss dialects of Wallis and in the Walser dialects (cf. Bohnenberger 1913: 15-16; Eufe and Mader 2018 for a recent survey).

7. We will come back to $-e t u /-u t u$ derivatives in section 4 . 
8. In addition, a couple of deadjectival verbs are also found, e.g. hialljun ('to caress') $<$ hial ('smooth'), hielljun ('to levigate') < hiel ('smooth') and miarun/mierun ('to increase, to raise') < mia/mier ('more').

9. Throughout this and the following sections the exemplification and the figures are based on Titsch data extracted from the ArchiWals corpus, but similar data are also found for Töitschu.

10. Unfortunately, vowel harmony is not consistently reported in the orthography and a certain variation is observed in the texts, as for instance katzun ('to kick') > katzetu / katzutu ('kicking'), pannulurun ('to paint') > panneleretu ('brush stroke'), etc. Moreover, it has to be added that vowel harmony also occurs in Titsch, although its effects are far less consistent than in Töitschu (cf. Zürrer 1999: $148 \mathrm{ff}$.). Accordingly, alternative forms in -òtò such as mésschlòtò ('mixture') and ofnòtò ('batch') are found besides mésschletò and ofnetò.

11. Cf. Henzen (1965: 175-176): 'Auf -ete (südalem. noch -eta; aus rom. -èta oder - atta?) gehen Feminina aus, die das Ergebnis einer Tätigkeit, namentlich aber eine gewisse Menge, die auf einmal erscheint, festhalten: Kochete, Backete was auf einmal gekocht, gebacken wird, Läutete Geläute, Lachete Gelache, Rechete das mit dem Rechen Zusammengeraffte, Gablete Gabel voll, Zeilete Zeile voll, Rechnete Abrechnung, Rechnung, Strickete Strickzeug, Scheissete, Kotzete, Schnud(e)rete Nasenschleim wie ahd. scīzāta, snuderāta, screiāta' [Feminine nouns which record the result of an activity, in particular however a certain quantity appearing at once, go back to -ete (southern Alemannic still -eta; from Romance -èta or -āta?): Kochete, Backete what is cooked, backed at once, Läutete ringing, Lachete laughing, Rechete what is snatched with the rake, Gablete fork full, Zeilete row full, Rechnete reckoning, account, Strickete knitting, Scheissete, Kotzete, Schnud(e)rete nasal mucus like GOH scizāta, snuderāta, screiāta.]

12. The suffix - ata goes back clearly to the generalisation of the original FPP with nominal bases as also witnessed by the occurrence of the intermediate verb resulting from a conversion in older stages of Italian as for instance ${ }^{+}$gomitare ('to blow with an elbow') and ${ }^{+}$occhiare ('to eye').

13. We thank Michele Musso (Associazione Augusta, Issime) for pointing out to us this example extracted from an interview recorded in August 2018 (cf. Busso 2018).

\section{References}

Angster, Marco (2012), 'Isolamento e contatto. Stratigrafia del lessico dei walser meridionali dai dati del PALWaM', Bollettino dell'Atlante Linguistico Italiano, 36: 155-200.

Angster, Marco (2014), 'Lingue di minoranza e di maggioranza. 200 anni di lingue straniere a Gressoney (AO)', in V. Porcellana and F. Diémoz (eds), Minoranze in mutamento. Etnicità, lingue e processi demografici nelle valli alpine italiane, Alessandria: Edizioni dell'Orso, pp. 105-121.

Angster, Marco and S. Dal Negro (2017), 'Linguistische Distanz einschätzen: Der Fall von Walserdeutsch im Licht von lexikalischen Daten und soziolinguistischen 
Parametern', in H. Christen, P. Gilles and C. Purschke (eds), Räume, Grenzen, Übergänge. Akten des 5. Kongresses der Internationalen Gesellschaft für Dialektologie des Deutschen (IGDD), Stuttgart: Franz Steiner Verlag, pp. 9-25.

Angster, Marco, M. Bellante, R. Cioffi and L. Gaeta (2017), 'I progetti DiWaC e ArchiWals', in L. Gaeta (ed.), Le isole linguistiche tedescofone in Italia: situazione attuale e prospettive future (Workshop 24 February 2017), Special Issue of Bollettino dell'Atlante Linguistico Italiano, 41: 83-94.

Antonietti, Federica, M. Valenti and M. Angster (2015), Piccolo Atlante dei Walser Meridionali, Aosta: Tipografia Valdostana.

Berruto, Gaetano (2018), '18. The Languages and Dialects of Italy', in W. AyresBennett and J. Carruthers (eds), Manual of Romance Sociolinguistics, Berlin and Boston: De Gruyter, pp. 494-525.

Bohnenberger, Karl (1913), Die Mundart der deutschen Walliser im Heimattal und in den Aussenorten, Frauenfeld: Huber.

Booij, Geert (2010), Construction Morphology, Oxford: Oxford University Press.

Busso, Vittoria (2018), 'Wi hewer mussu weerhun! Quanto lavoravamo!', Augusta, 50: 69-71.

Dixon, Robert M. W. (2005), A Semantic Approach to English Grammar, Oxford: Oxford University Press, 2nd edn.

Eufe, Rembert and A. Mader (2018), 'Das Walserdeutsche im deutschen und italienischen Sprachgebiet', in N. Eller-Wildfeuer, P. Rössler and A. Wildfeuer (eds), Alpindeutsch. Einfluss und Vermendung des Deutschen im alpinen Raum, Regensburg: Edition vulpes, pp. 113-139.

Gaeta, Livio (2002), Quando i verbi compaiono come nomi. Un saggio di Morfologia Naturale, Milano: Angeli.

Gaeta, Livio (2008), 'Die deutsche Pluralbildung zwischen deskriptiver Angemessenheit und Sprachtheorie', Zeitschrift für germanistische Linguistik, 36: 1, 74-108.

Gaeta, Livio (2015), 'Action Nouns in Romance', in P. O. Müller, I. Ohnheiser, S. Olsen and F. Rainer (eds), Word-Formation. An International Handbook of the Languages of Europe, Berlin and New York: De Gruyter, vol. 2, pp. 1165-1185.

Gaeta, Livio (2017), 'Nomi deverbali in MIDIA', in P. D'Achille and M. Grossmann (eds), Per la storia della formazione delle parole in italiano, Roma: Cesati, pp. 221-241.

Grandi, Nicola (2015), 'Evaluative Morphology and Number/Gender', in N. Grandi and L. Körtvélyessy (eds), Edinburgh Handbook of Evaluative Morphology, Edinburgh: Edinburgh University Press, pp. 91-107.

Henzen, Walter (1965), Deutsche Wortbildung, Tübingen: Niemeyer, 3rd edn.

Russ, Charles V. J. (1990),'Swabian. High Alemannic', in C. V. J. Russ (ed.), The Dialects of Modern German, London: Routledge, pp. 337-393.

Štekauer, Pavol (2014), 'Derivational Paradigms', in R. Lieber and P. Štekauer (eds), The Oxford Handbook of Derivational Morphology, Oxford: Oxford University Press, pp. 354-369.

Storrer, Angelika (2006), 'Zum Status der nominalen Komponenten in Nominalisierungsverbgefügen', in E. Breindl, L. Gunkel and B. Strecker (eds), Grammatische Untersuchungen. Analysen und Reflexionen. Gisela Zifonun zum 60. Geburtstag, Tübingen: Narr, pp. 275-295. 
Timberlake, Alan (2004), A Reference Grammar of Russian, Cambridge: Cambridge University Press.

Vendler, Zeno (1967), Linguistics in Philosophy, Ithaca, NY: Cornell University Press.

Wohlgemuth, Jan (2009), A Typology of Verbal Borromings, Berlin and New York: De Gruyter.

Zürrer, Peter (1999), Sprachinseldialekte. Walserdeutsch im Aosta-Tal (Italien), Aarau, Frankfurt am Main and Salzburg: Sauerländer.

Zürrer, Peter (2009), Sprachkontakt in Walser Dialekten. Gressoney und Issime im Aostatal (Italien), Stuttgart: Steiner. 